\title{
The Role of China in Global Energy Governance
}

\section{Gaye Christoffersen}

\section{OpenEdition}

\section{Journals}

Electronic version

URL: http://journals.openedition.org/chinaperspectives/6968

DOI: 10.4000/chinaperspectives.6968

ISSN: 1996-4617

\section{Publisher}

Centre d'étude français sur la Chine contemporaine

\section{Printed version}

Date of publication: 1 June 2016

Number of pages: $15-24$

ISSN: 2070-3449

\section{Electronic reference}

Gaye Christoffersen, «The Role of China in Global Energy Governance », China Perspectives [Online], 2016/2 | 2016, Online since 01 June 2017, connection on 28 October 2019. URL : http:// journals.openedition.org/chinaperspectives/6968; DOI : 10.4000/chinaperspectives.6968 


\section{The Role of China in Global}

\section{Energy Governance}

\section{GAYE CHRISTOFFERSEN}

ABSTRACT: Global energy governance institutions pressure China, which has ungoverned domestic energy spaces, to reform and strengthen its capacity for domestic energy governance. Rather than reform, China has attempted to create an alternative global energy order and establish a leadership role using the BRICS framework. However, BRICS exist in the global ungoverned energy space and have not prioritised energy governance. Additionally, BRICS practice shared leadership, undermining potential Chinese leadership. Beijing has subsequently shifted to the "Silk Road Economic Belt," a vehicle for uncontested Chinese leadership in energy.

KEYWORDS: energy security, global governance, BRICS, energy diplomacy, Russia.

\section{Introduction(1)}

G lobal energy security is put at risk by the uneasy relationship between the international political system and the international energy system. The political framework of the International Energy Agency (IEA) was created to manage energy security in the developed world and in relations with producing countries in OPEC. Both recognise a need for a more comprehensive producer-consumer dialogue. However, the everexpanding energy demand of the developing world, the "globalisation of energy demand," and the emergence of non-OPEC producing countries that now account for $60 \%$ of world oil production fall outside of that framework. China, the world's largest net oil importer, remains outside the IEA, as does India. Their resistance to the norms of global energy governance makes them reluctant to participate in these international institutions, producing gaps in global energy governance. It is in the ungoverned space of world oil production and consumption that China implements its resource diplomacy and promotes alternative institutions.

Beijing began its association with the IEA in 1996 as a non-member economy, holding workshops and seminars. There is a special IEA office for relations with China. For China, membership in the IEA would be difficult due to the requirement of holding a 90-day strategic petroleum reserve (SPR). As a non-member, China is reluctant to disclose petroleum data to the IEA, which Chinese feel only serves the interests of OECD members rather than the good of the international community.

The strongest platforms for Chinese participation in global energy governance are situated in OECD countries, such as the IEA, the Energy Charter, and numerous energy research institutions. These $\mathrm{OECD}$ resources can best help reform Chinese domestic energy governance. However, China's further integration into the current energy governance system would require further domestic energy policy reform.

Alternatively, China could restructure the global energy governance system in such a way as to put less pressure for reform on its domestic energy economy. Chinese energy diplomacy has thus concentrated on constructing an alternative energy governance structure in the BRICS organisation, the Shanghai Cooperation Organisation (SCO), and in Central Asia through the Silk Road initiative.
The construction of international energy institutions is generally understood within the liberal institutionalist approach. This theoretical approach is useful for the topic of Chinese domestic and international energy politics because it does not draw a hard line between domestic and international politics. (2) The approach is also useful as it treats international institutions as a solution for overcoming dysfunctionalities, the "dark underbelly" of corruption in the world oil economy. The liberal institutionalist approach has embedded in it the promotion of certain liberal values - corporate social responsibility, transparency, regulation of illicit trade, good governance, economic liberalisation - that are meant to create global and regional order. ${ }^{(3)}$ These are values that the IEA promotes but would not necessarily be promoted by the BRICS. BRICS domestic energy governance in China, Russia, and Brazil is plagued by corruption, and does not conform to best practices. Central Asia's energy-producing countries have similar problems.

China and the other BRICS nations have not elaborated on a theory appropriate for their alternative international energy institutions. Chinese scholars recognise China's theory deficit in global governance. ${ }^{(4)}$ Chinese have said they want new rules and institutions for global energy governance but have not defined them.

Russian scholar Dmitri Trenin, addressing a Chinese audience, warns BRICS that seeking a new world order will not be realised by overthrowing the existing US-led world order but rather by a triumph of "global best practices" as viable alternatives to current business practices. But they can do this only if their global institution-building goes beyond anti-Western declarations. ${ }^{(5)}$

Beijing and Moscow pose a challenge to the West's liberal world order. As their identities evolve in alienation from Western values, their domestic authoritarianism drives them to restructure their external environment. (6)

1. This paper was originally presented at the $28^{\text {th }}$ Annual Meeting of the Association of Chinese Political Studies, "China and the Changing World Order: Domestic and Global Dimensions," co-sponsored by the School of International Studies, Peking University, 6-7 June 2015, Beijing, China.

2. Roland Dannreuther, "International Relations Theories: Energy, Minerals and Conflict," POLINARES working paper, No. 8, September 2010, p. 6.

3. Ibid., pp. 7-8.

4. Cai Tuo, "Global Governance: A Chinese Perspective and Practice," in Cai Tuo (ed.), Chinese Perspectives on Globalization and Autonomy, Leiden, Brill, 2012, p. 49

5. Dmitri Trenin, "Russia Far From Isolated in Non-West Community," China Daily, 8 July 2015.

6. Gilbert Rozman, The Sino-Russian Challenge to the World Order: National Identities, Bilateral Relations, and East versus West in the 2010s, Stanford, Stanford University Press, 2014. 
Russia, with aspirations to lead the BRICS, should have been a source of concrete initiatives but has hedged instead. Vladimir Putin's speech at the UN General Assembly in September 2015 was critical of the current world order but lacked concrete proposals for an alternative world order. In December 2015, a Russian documentary, World Order, was very critical of the US-led world order but portrayed Putin as continuing to rely on its institutions, such as the UN Charter. ${ }^{(7)}$

In July 2015, Putin enthusiastically hosted the BRICS Summit and SCO Summit jointly to demonstrate that Russia was not isolated by Western sanctions but rather was an emerging leader, in conjunction with China, of an alternative world order. The BRICS share with the SCO an alienation with Western-led global institutions, and the Sino-Russian partnership is important to both groups. ${ }^{(8)}$

China has also hedged. Feiling Wang has noted that Beijing wants the benefits of both the Westphalian system and the Sino-centric order. This leads to a profound disjointedness in Chinese foreign policy, ranging from integrating into the Westphalian system to displacing it with a Chinese world order. ${ }^{(9)}$

American sceptics believe China, as the rising hegemon, is promoting a de-legitimation of the US-led world order and is attempting to construct an alternative world order. They argue that China simultaneously pursues the role of spoiler, supporter, and shirker of the current world order. ${ }^{(10)}$

China has framed the question of regional order as based on geography with China at its centre in a Sino-centric order. The Silk Road Economic Belt (SREB) and the $21^{\text {st }}$ Century Maritime Silk Road (One Belt One Road, or $\mathrm{OBOR}$ ) are geographically based with China at the centre.

Geography does not support Chinese leadership of the BRICS, however. Therefore, a non-geographic, abstract concept, "the power shift," is used in a Chinese narrative that claims the power shift is drawing China into a greater role in global governance based on growing GDP, expanding exports, and military capability. According to the narrative, a sustainable global order is only possible with China participating in global governance. (11)

A study on Chinese and Indian perspectives of global order found areas of convergence and divergence but not an emerging BRICS perspective that would indicate consensus on what kind of global order the BRICS might want. ${ }^{(12)}$

BRICS Summits have supported access to affordable clean energy, the need to strengthen producer-consumer dialogues, and greater cooperation in energy efficiency, R\&D, and technology transfer. BRICS energy policy does not diverge from Western international energy institutions in any of these areas, which may be one reason why there is not yet any BRICS alternative international energy institution.

A few years ago, John Ikenberry warned that the trend of constructing geopolitical blocs would fragment the US-led liberal world order and break down its institutions. ${ }^{(13)}$ Ikenberry later reconsidered his position, arguing that the global order is not that fragile, and that both Russia and China are deeply integrated into current governing institutions. ${ }^{(14)}$

This paper will examine Chinese efforts to construct an alternative energy governance structure in the BRICS organisation. For various reasons, these efforts evolved into an effort to create an autonomous energy system with Central Asia and the Middle East under the framework of the "Silk Road Economic Belt," a program of the Xi Jinping government. This paper examines Chinese discontent with the existing global energy governance system, part of a wider discontent with Western-led global governance that was a prelude to proposing the "Silk Road Economic Belt."

\section{China within Western global energy governance}

Global energy governance requires rules and institutions that form an institutional architecture undergirding world oil and gas markets. Existing institutions are being challenged by China and India's rapidly increasing oil and gas demand. ${ }^{(15)}$ China's past under-participation and limited capacity in Western international institutions - ideationally and financially - has long been noted. ${ }^{(16)}$

Global energy governance has few strong international institutions. Both the IEA and OPEC are under-institutionalised, with only partial membership from oil importing and exporting countries. ${ }^{(17)}$ This leaves the global energy governance system vulnerable to challenges. Both IEA and OPEC recognise the need for a more comprehensive producer-consumer dialogue.

Global energy governance is defined as "Making and enforcing rules to avoid the collective action problems related to energy at a scale beyond the nation-state." The current global energy governance structure has many gaps. The rules and institutions of global energy governance have emerged ad hoc rather than as the result of coherent strategies.

Global energy governance as constructed by the developed countries has been criticised as inadequate to meet numerous challenges: unreliable supply of energy fuels, massive environmental degradation, and failure to provide modern energy resources to a large part of the global population. ${ }^{(18)}$

Analysts identify six types of global energy governors: intergovernmental organisations such as UNDP and IEA, summit processes such as BRICS, international nongovernmental organisations such the World Resources Institute, multilateral financial institutions such as the World Bank, and regional organisations such as APEC. The World Bank and the Asian Development Bank, with technical expertise and finances, have significant influence on Asia's energy technology, regulation, and policy through their investment in energy infrastructure. They are expected to take a leadership

7. Ivan Tsvetkov, "World Order in 2015 as Seen by Putin," Russia Direct, 28 December 2015, www.russia-direct.org/opinion/world-order-2015-seen-putin (all URLs accessed on 17 April 2016).

8. Fred Weir, "Back-to-back Russia-hosted Summits Put Putin in Coveted Starring Role," Christian Science Monitor, 8 July 2015.

9. Feiling Wang, "From Tianxia to Westphalia: The Evolving Chinese Conception of Sovereignty and World Order," in G. John Ikenberry, Wang Jisi, and Zhu Feng (eds), America, China, and the Struggle for World Order: Ideas, Traditions, Historical Legacies and Global Visions, New York, Palgrave Macmillan, 2015, pp. 43-70.

10. Randall L. Schweller and Xiaoyu Pu, "After Unipolarity: China's Visions of International Order in an Era of U.S. Decline," International Security, Vol. 36, No. 1, Summer 2011, pp. 41-72.

11. Qin Yaqing, "Power Shift, Governance Deficit and a Sustainable Global Order," Economic and Political Studies, Vol., 1 No. 1, January 2013, pp. 89-106.

12. Ashley J. Tellis and Sean Mirski (eds), Crux of Asia: China, India and the Emerging Global Order, Washington, DC, Carnegie Endowment for International Peace, January 2013, www.carnegieendowment.org/files/crux_of_asia.pdf.

13. G. John Ikenberry, Liberal Leviathan:The Origins, Crisis, and Transformation of the American World Order, Princeton, Princeton University Press, 2011.

14. G. John Ikenberry, "The Illusion of Geopolitics: The Enduring Power of the Liberal Order," Foreign Affairs, Vol. 93, No. 3, May/June 2014.

15. Andreas Goldthau and Jan Martin Witte (eds), Global Energy Governance: The New Rules of the Game, Washington, DC, Brookings Institution, 2010, p. 2.

16. Hongying Wang and Erik French, "China's Participation in Global Governance from a Comparative Perspective," Asia Policy, No. 15, January 2013, pp. 89-114.

17. Ann Florini argues that there is an urgent need for global coordination of energy resources, and further argues that existing institutions such as the International Energy Agency (IEA) are not up to the task: "Lost Generation: Governance Gone Missing in Global Energy Security," webcast, University of Melbourne, http://upclose.unimelb.edu.au/episode/168-lost-generation-governancegone-missing-global-energy-security.

18. Ann Florini and Benjamin K. Sovacool, "Bridging the Gaps in Global Energy Governance," Global Governance, Vol. 17, No. 1, January-March 2011, pp. 57-74 
role in low-carbon development but are criticised for relying too heavily on market mechanisms, not integrating environmental and social considerations into their financing of energy projects, putting priority on developed countries' interests, and failing to give developing countries more voice. ${ }^{(19)}$

Western global energy governance has focused on the Energy Charter and encourages emerging economies to join it. The Energy Charter of 1994 is a multilateral treaty with legally binding provisions for the promotion and protection of energy investments, transport, trade, and the reduction of risk. Membership includes producing, consuming and transit countries. ${ }^{(20)} \mathrm{Chi}$ nese energy reformers are responsive to these initiatives. In 2015, during a visit to Beijing by Ambassador Rusnak, Secretary General of the Energy Charter, China's Energy Research Institute held an "Energy Charter and Global Energy Governance Workshop" attended by the National Development and Reform Commission, the National Energy Administration, the International Department of the Central Committee of the Chinese Communist Party (CCP), the Ministry of Foreign Affairs, and many other government agencies.

China became an observer country to the Energy Charter in 2011. China is a participant in the Task Force for Regional Energy Cooperation in Central Asia, and participates in negotiations for a World Energy Charter launched in 2014. The Energy Charter has given China a platform within the current global energy governance system.

The Chinese Energy Research Institute, under the National Development and Reform Commission (NDRC), and the Grantham Institute for Climate Change, Imperial College in London, created a joint project for enhancing China's participation in the current global energy governance system while also considering potential reform of the system. The resulting report made recommendations for jointly building a new international energy order: promote G20 leadership of the system, and integrate developing countries and the BRICS into the organisations of global energy governance.

Recommendations for China: strengthen China's modern governance capacity in the energy sector and modernise energy management capacity related to global energy governance; strengthen China's ability to use international energy rules and shape international energy issues; strengthen capacity for using energy diplomacy; greater awareness of the international dimension of energy policies related to international energy markets; improved ability to explain energy policies internationally; establishment of consultation mechanisms for international energy cooperation and energy diplomacy. ${ }^{(21)}$

All of the report's recommendations placed enormous demands for domestic reform and modernisation on China's energy producers, consumers, and institutions. It was assumed that with this domestic transformation, China would engage more positively in Western global energy governance. (22)

\section{China's domestic energy governance capacity}

There are ungoverned spaces in China's domestic energy production and consumption, a lack of energy governance that makes China vulnerable to the world oil market, increases its sense of insecurity, and leads to perpetual debates on China's energy security. Uncontrolled domestic oil demand leading to a rapid increase in oil imports, crude oil and petroleum product smuggling, and independent "teapot" refineries are some of the activities in the ungoverned space. China's national oil companies (NOCs) - CNPC,
Petrochina, Sinopec, CNOOC - investing in overseas oil fields, appeared to operate in ungoverned space globally, beyond the reach of the state, until the anti-corruption campaign decimated their leadership beginning in 2013.

Debates over China's dependence on oil imports have continued for two decades. In these debates inadequate governance of the domestic energy sector is identified as the biggest threat to China's energy security. ${ }^{(23)}$ Chinese analysts identify numerous causes of energy ungovernability: the central government is fragmented, provincial actors diverge from the centre, and the NOCs differ from both the centre and the localities on domestic energy governance. It is the impact of globalisation during the economic reforms that has led to a decay in China's capacity for domestic energy governance. (24)

Lack of transparency in China's energy policymaking and energy data is a problem for both domestic governance and global energy governance. It is in fact considered a state secret how Beijing makes energy policy. As China became the world's largest oil importer in 2015, its domestic ungoverned spaces became a problem for world oil markets.

Since the beginning of the economic reforms, Beijing has reorganised the energy bureaucracy multiple times. Each time has been an effort to more rationally manage energy demand and supply. A Ministry of Energy was created in 1988, but it was quickly disbanded due to pressure from energy industry interests. For three decades energy reformers have tried to shift investment into energy efficiency and conservation but have been countered by powerful opponents - the coal industry and the NOCs. China's efforts to control domestic energy demand have increasingly had to consider the linkage between domestic and international policies due to its regional environmental impact.

In 2003, Chinese oil demand rapidly escalated, as did oil imports, leading to an "energy crisis" followed by a "Malacca Strait dilemma," increasing vulnerability to interruption of oil supply by blocking China's access to the sea. Energy reformers in the NDRC's Energy Research Institute (ERI) and the State Council's Development Research Centre produced a joint study outlining an energy strategy for China. The strategy would have China controlling domestic demand by joining international energy institutions in order to implement energy efficiency policies. The final draft was issued in June 2004. (25)

A 2005 reorganisation of the energy bureaucracy created a National Energy Leading Group (NELG) whose responsibility it was to provide guidance in national energy planning and to promote international cooperation. A National Energy Office was established to implement NELG policies and coordinate NDRC energy functions. (26) Reorganisation of the Chinese energy bureaucracy was helpful for participation in multilateral energy cooperation.

19. Smita Nakhooda, "Asia, the Multilateral Development Banks and Energy Governance," Global Policy, Vol. 2, 2011, pp. 120-132.

20. Guojia fazhan he gaige weiyuanhui nengyuan yanjiusuo (Energy Research Institute National Development and Reform Commission, ERI), "Energy Charter and Global Energy Governance Workshop," 2 February 2015, http://eng.eri.org.cn/news_z.pphp?cid=27\&aid=512.

21. Energy Research Institute, NDRC and Grantham Institute for Climate Change, Imperial College London, Global Energy Governance Reform and China's Participation: Consultation Draft Report, February 2014, pp. 41-44.

22. Ibid., p. 44.

23. Michal Meidan, "China's Energy-security Debate Redux," Survival blog, 31 May 2014.

24. Bo Kong, "Governing China's Energy in the Context of Global Governance," Global Policy, Vol. 2, 2011, pp. 51-65.

25. Development Research Centre of the State Council and the Energy Research Institute, China National Energy Strategy and Policy 2020, Beijing, June 2004.

26. "China to Set Up Task Force Dealing with Growing Energy Crisis," Petroleumworld, 2 May 2005. 
The energy bureaucracy was reorganised again in 2008. The Energy Bureau was transformed into the National Energy Administration (NEA), taking on the functions of the Bureau, the Department for Energy Efficiency, and the Commission of Science, Technology and Industry for National Defence (COSTIND). The NEA was given responsibility for international energy cooperation, approval of foreign energy investments, management of strategic petroleum reserves, and oversight of energy industries, including the Chinese NOCs. The National Energy Leading Group was reorganised into the $\mathrm{Na}$ tional Energy Commission with responsibility for coordinating energy policy. (27) There was scepticism over this new re-organisation, with no expectation that these new organisations would have greater authority over the Chinese NOCs than previous agencies. ${ }^{(28)}$ The NOCs had always drawn resources away from investment in energy efficiency in favour of investing in increasing supply. In 2012 China NOCs invested \$25 billion in overseas energy assets. This was 39\% more than in 2011.

On 10 March 2013, Beijing announced that the State Council was once again being reorganised, the seventh time since the economic reforms began. Energy bureaucracies were also redesigned to improve their domestic efficiency. The State Electricity Regulatory Commission (SERC) was folded into the National Energy Administration. Prior to reorganisation, the NEA and SERC had overlapping functions and responsibilities in the electricity sector. The NEA's responsibilities included drafting and implementing energy development strategies, plans, and policies, and strengthening implementation of energy efficiency policies. On 20 March, SERC denied that it was being dissolved. On $25 \mathrm{March}$, the former head of SERC was appointed head of the NEA.

The NEA needed to address problems that persisted over the past three decades: the need to change the energy mix, reduce coal consumption (coal is generally used for power generation), increase renewable energy use, reduce oil imports, which were approaching $60 \%$ of domestic oil consumption, and change China into a low-carbon society.

\section{Chinese global energy governance}

People's Daily declared in July 2011 that China's participation in global energy governance and climate change negotiations was an important strategic goal for China's energy diplomacy. The editorial argued that participation in global governance would help China realise good domestic energy governance and also increase Chinese influence in the world. The newspaper claimed that China's current status in global governance was not in keeping with its status as the world's largest oil importer. China needed to create a new framework for global energy governance, one that gave China a larger role and greater status. ${ }^{(29)}$

The implications of this statement were: China has not managed domestic energy governance very well, which has resulted in China becoming the world's largest oil importer. This domestic governance failure is given as the reason China is qualified to rewrite the rules and re-organise the institutions of global energy governance. The ultimate Chinese purpose is to give China greater status in global energy issues.

At the World Future Energy Summit in Abu Dhabi in 2012, Chinese Premier Wen Jiabao proposed the creation of rules governing global energy supply overseen by an international body to govern energy markets for greater stability. Wen called for creation of a G20-type organisation to administer "fair, reasonable, and binding" global rules that would stabilise oil and natural gas markets. ${ }^{(30)}$
Some Chinese analysts warned that China is too fragmented to have a unified voice on global energy governance. Consequently, China lacked the capacity to upset or challenge the global energy order, and was uncertain as to its role in global energy governance. (31) Other analysts, such as Xu Xiaojie, argued that in the realm of global oil markets, China has not been passive. China has been called the "Black Energy Swan," which means China is a steady source of surprise - black swan events - in the world oil economy due to its insatiable rising domestic oil demand and its unpredictable international behaviour.

Xu Xiaojie noted that relations with the US have been strained because this Black Energy Swan has "incompatible cultures, conflicts of interest, and lack of shared rules" with the US. China has the potential to become a White Energy Swan, which would mean that Chinese energy behaviour would be more transparent, responsible, comprehensible, and predictable, and would follow international rules and practices. A new world order would need to be created with new rules before China could become a White Energy Swan. A new concept of energy security was needed, one that included security of oil demand with security of oil supply. The international institutions best suited for China's transformation into a White Swan were the Shanghai Cooperation Organisation, the G20, and the BRICS, where China has a role to play and influence over the rules. ${ }^{(32)}$

Russia in many ways has also constituted a "Black Energy Swan," its energy policy choices impacting global energy security. The IEA's World Energy Outlook 2011 included an in-depth study of Russia's energy sector. Russia has an uncertain investment climate and tax regime, poor energy efficiency, and declining production. ${ }^{(33)}$ The critique of Russian policymakers is that they are overly concerned with collecting the rent of oil wealth and short payback time, and insufficiently concerned with long-term investment in oil production and infrastructure. ${ }^{(34)}$ With declining production, Russia needs to focus on developing new fields. In June 2011, the IEA reportedly pleaded with Russia (and OPEC) to join with the IEA in brokering an agreement between producers and consumers that would solve what was then a crisis of high oil prices. The IEA urged OPEC to increase production. Producing countries, Russia and OPEC, blamed high prices on the financialisation of the oil market. ${ }^{(35)}$

Some Chinese felt international organisations such as the IEA excessively criticised Chinese energy consumption practices as China became the largest emitter of greenhouse gases. The IEA pushed Beijing to reduce carbon emissions and take more responsibility, what Chinese called the "theory of

27. Phillip Andrews-Speed, The Governance of Energy in China:Transition to a Low-Carbon Economy, Houndmills, Basingstoke, Palgrave Macmillan, 2012, pp. 146-147.

28. Erica Downs, "China's 'New' Energy Administration," China Business Review, November-December 2008, www.brookings.edu/research/articles/2008/11/china-energy-downs.

29. "Participating in Global Energy Governance Is a Strategic Choice for China's Foreign Energy Policy," People's Daily, 27 July 2011, http://english.people.com.cn/100668/102793/102795/7453 508.html\#.

30. David Worthington, "China Proposes Global Energy Governance, Development," ZDNet.com, 16 January 2012, www.zdnet.com/article/china-proposes-global-energy-governance-development.

31. Bo Kong, "Governing China's Energy in the Context of Global Governance," art. cit.

32. Xu Xiaojie, "Black Energy Swan: A Global Perspective," Center on Environment, Energy and Resource Policy, Hong Kong University of Science \& Technology, 17 May 2012; Xu Xiaojie, Energy Black Swan: Global Games and Chinese Options, Beijing, China Social Sciences Press, 2011.

33. IEA, World Energy Outlook 2011, www.worldenergyoutlook.org/weo2011.

34. Stefan Hedlund, "Rents, Rights, and Service: Boyar Economics and the Putin Transition," Problems of Post-Communism, Vol. 55, No. 4, July/August 2008, pp. 29-41.

35. Terry Macalister, "Head of IEA Pleads with Russia: Join Us to Help Solve Energy Price Crisis," The Guardian, 18 June 2011, www.guardian.co.uk/business/2011/jun/18/international-energyagency-russia-join-us. 
China's energy responsibility" (Zhongguo nengyuan zeren lun 中国能源责 任论). ${ }^{(36)}$ Chinese reject the notion that China has any responsibility to the world regarding its energy consumption.

In the dimension of global energy governance, the question is: can the Chinese Black Energy Swan expand its role in global energy governance, revise the rules and institutions of that governance to suit its own preferences, in ways that the international community would find acceptable? Can China use this global energy governance to reform domestic energy governance, or will Chinese domestic governance practices, very weak on rules and institutionalisation, undermine global energy governance and governability?

Beijing feels restricted by current international institutions created by the West. The IEA and China have had running disagreements regarding China's impact on world oil demand. The IEA has criticised Beijing for China's continually expanding oil demand, warning in 2007 that "In the next five years, almost half of global oil demand growth will come from China, and this trend is set to continue to 2035, as oil demand from the transportation sector is growing strongly in countries such as China and India." (37) The IEA focused on Chinese and Indian energy demand in World Energy Outlook 2007: China and India Insights. ${ }^{(38)}$

For the past two decades, China has been promoting the idea that there is a need for a new international political and economic order that would counter the global order shaped by the West and especially the US. It was strong on rhetoric but failed to gain an international following. The 2008 global financial crisis created opportunities to more intensely challenge the existing order. The emergence of the BRICS (Brazil, Russia, India, China, and South Africa) created an additional opportunity of multi-polarity, something Beijing has hoped for since the end of the Cold War, which would counter US hegemony and the US unipolar moment. ${ }^{(39)}$

There is a Chinese narrative emerging on why greater Chinese participation is needed in global governance because there is a global governance deficit, a gap between world demand for global governance and the inability of existing international institutions to meet that demand. The emerging powers, BRICS, and especially China should be given larger roles in these institutions alongside the US and Europe to create a more sustainable world order. ${ }^{(40)}$ In contrast, Western analysts contend that China is only a partial power with a constrained global governance capacity. ${ }^{(41)}$

As China makes the case for new institutions for global energy governance, it may be exaggerating its differences with the IEA. In November 2015, the Chinese Energy Administration and the IEA signed a joint statement for their joint program during 2016-2017. During their meeting, they noted the "(...) progress made in China-IEA co-operation in areas of energy security, energy policy dialogue, renewables, energy efficiency, energy data and statistics, energy technology (...)" (42) Later in November 2015, Beijing hosted a joint workshop on IEA-NEA Policy Dialogue on Oil and Gas Development.

\section{Chinese energy diplomacy: Building capacity for global energy governance}

In 2007, Chinese analysts put responsibility for Chinese energy insecurity on lack of state capacity to control the Chinese oil industry domestically and internationally, and the enduring problem of energy policy incoherence. China did not have a government agency that could coordinate implementation of its energy diplomacy. The analysts proposed that China form energy partnerships that would facilitate greater institutionalisation. ${ }^{(43)}$
China's interest in global energy governance is a result of Chinese NOCs' going-out strategy to secure physical access to oil resources. China uses energy diplomacy to facilitate Chinese NOCs' oil acquisitions in regions they would have difficulty accessing on their own. ${ }^{(44)}$ China has also been placing more emphasis on energy in its foreign policy agenda, and on energy diplomacy, in order to limit China's exposure to the world oil market, to exert greater political control over overseas energy activities, and to participate more effectively in global energy governance.

The NOCs had persuaded the central government to politically and economically underwrite their overseas investments. This led to the Ministry of Foreign Affairs cultivating relations with oil-producing states that gave China a larger diplomatic presence in the Middle East, Central Asia, and Africa. ${ }^{(45)}$ China's high-profile oil diplomacy, its energy "going-out strategy," was driven by the perceived need for more secure national control of overseas oil and gas supplies rather than directly purchasing oil on the world oil market.

China's energy diplomacy (nengyuan waijiao 能源外交) or resource diplomacy (ziyuan waijiao 资源外交) has become more important in China's search for oil and gas in Central Asia, Africa, and Latin America, areas where oil companies and the Chinese Ministry of Foreign Affairs needed to work together to establish a Chinese presence. Energy diplomacy was especially needed in the Middle East, with OPEC, the IEA, and numerous other energyrelated international organisations. Diplomacy was meant to promote China's energy interests in regions where Chinese companies cannot gain access by themselves. ${ }^{(46)}$ In conjunction with enhanced diplomatic activity, the Chinese government has supplied economic aid and military technology to oil producing countries.

A key factor for China's success in securing oil resources overseas is to exclude competitors' interference in access to those resources. ${ }^{(47)}$ One strategy for doing so would be to bring neighbouring countries' resources within a Sino-centric order, for example Myanmar and Kazakhstan. Another Chinese strategy has been to find its niche within the world oil economy by investing in those countries considered rogue states, violators of human security, countries that the oil majors and other national oil corporations have not

36. "Zhongguo 'nengyuan zeren lun' keyi xiu yi" (The "theory of China's energy responsibility" can be laid to rest), Guangming ribao, 4 August 2010, http://cpc.people.com.cn/GB/64093/ 64387/12340897.html.

37. IEA, FAQs, "Oil," www.iea.org/aboutus/faqs/oil.

38. IEA, World Energy Outlook 2007: China and India Insights, www.iea.org/publications/freepublications/publication/weo-2007---special-report---focus-on-china-and-india.html.

39. Ming Jinwei, "What Can World Learn from BRICS Summit in Sanya?", Xinhua (Embassy of the PRC in the Republic of India website), 15 April 2011, www.fmprc.gov.cn/ce/cein/eng/ zt/bric/t815919.htm.

40. Qin Yaqing, "Power Shift, Governance Deficit and a Sustainable Global Order," Economic and Political Studies, Vol. 1, No. 1, January 2013, pp. 89-106.

41. David Shambaugh, "The Illusion of Chinese Power," The National Interest, No. 132, July-August 2014, pp. 39-48.

42. IEA, "Chinese NEA Administrator and IEA Head Meet in Paris," 19 November 2015, www.iea.org/newsroomandevents/news/2015/november/chinese-nea-administrator-and-ieahead-meet-in-paris.html.

43. Zha Daojiong and Hu Weixing, "Promoting Energy Partnership in Beijing and Washington," The Washington Quarterly, Vol. 30, No. 4, autumn 2007, p. 109

44. Pan Guang, "30 Years of Reform and Opening Up of China's Energy Diplomacy," China International Studies, No. 13, winter 2008, pp. 85-100, www.ciis.org.cn/english/2010-11/04/content_3815 122.htm.

45. Philip Andrews-Speed, The Governance of Energy in China, London, Routledge, 2012, p. 151.

46. Pan Guang, "30 Years of Reform and Opening Up of China's Energy Diplomacy," art. cit.

47. Sun Xuefeng and Wang Haibin, "China's Strategic Options to Tapping the World's Crude Oil Resources," Journal of Contemporary Asia-Pacific Studies, No. 1, 2010, pp. 57-78. 
been allowed to invest in because of their pariah status. Another dimension of energy diplomacy related to rogue states has been China's use of its veto in the UN Security Council to protect countries such as Iran from sanctions. All these practices generate criticism from the West.

The IEA has critiqued Chinese overseas oil investments, especially the Chinese NOCs' niche strategy of investing in rogue nations. After Chinese difficulties with political risks in Sudan, the IEA asked "Are the NOCs finally paying the price for investing in the most risky countries in the world?" (48)

Chinese contended that the IEA worked in the interests of the OECD countries, the developed world, "a club of rich countries," although the IEA claimed to be representing the entire world in global energy governance. ${ }^{(49)}$ The IEA's emphasis on best practices, which was perceived as hostility to Chinese practices, increased the need for Chinese energy diplomacy to counter the negative images generated by Chinese NOCs' association with rogue states.

In 2002, in preparation for developing China's capacity for energy diplomacy, energy experts studied Russian, American, and Japanese energy diplomacy and oil security strategies, trying to ascertain how China could strengthen its institutional capacity for foreign energy diplomacy. The lesson Chinese energy analysts took away from the comparative analysis was that China not only needed to strengthen its own domestic institutional capacity for energy diplomacy, but also needed to strengthen or create international energy mechanisms to better cooperate with these major oil producing and consuming countries. ${ }^{(50)}$ Greater cooperation with these states would strengthen China's capacity to withstand oil shocks. ${ }^{(51)}$

According to a professor from Shanghai Jiaotong University, Zhang Jianxin, China's oil diplomacy has numerous functions: maintaining political relations with oil exporting states, employing diplomatic efforts to maintain security of the sea lines of communication used to transport oil to China, fending off a third country's efforts to disrupt bilateral oil relations, and "melting down the diplomatic art by enmity states to implement oil trade embargo against China," a hypothetical function at present, since there are no oil embargos against China, although this may be an over-the-horizon Chinese concern. Oil-based diplomacy was manifested in several ways: Chinese Presidential diplomacy, regional diplomacy in organisations such as the SCO or APEC, great power diplomacy with the US and Russia, and multilateral diplomacy with the IEA. ${ }^{(52)}$

In 2006, emphasis on energy security was added to Hu Jintao's diplomatic agenda. James Tang argues that Energy Diplomacy became the third pillar of Hu's foreign policy strategy, added to Great Power Diplomacy (daguo waijiao 大国外交) and Good Neighbour Diplomacy (zhoubian waijiao 周边 外交). ${ }^{(53)}$

The first volume on the theory and practice of China's energy diplomacy, published in 2012, pinpoints interest in energy diplomacy to July 2006, when $\mathrm{Hu}$ Jintao participated in the $\mathrm{G} 8$ meeting discussions on energy security, and then December 2006, the time of the Five Country Energy Ministerial Meeting in Beijing. These meetings provided impetus for the Beijing government to put greater emphasis on energy diplomacy. ${ }^{(54)}$ The 2012 volume argued that no country could cope with energy security issues on its own, necessitating international cooperation, which in turn produced a need for a distinct discipline of energy diplomacy.

After several years of implementing Chinese energy diplomacy, dominated by Chinese NOCs, a backlash emerged accusing Chinese NOCs of singlemindedly pursuing commercial oil interests that undermined the government's much wider array of overseas interests. ${ }^{(55)}$ The overseas investments of NOCs often created political difficulties that diplomats were then called in to clean up. ${ }^{(56)}$ In 2008, Zhu Feng argued that NOCs such as CNPC had ignored broader national interests in their pursuit of profits, and had highjacked China's foreign policy in places such as Sudan. China was criticised for oil investments in Sudan during the time of human rights atrocities in the Darfur region. Zhang Yunling, Director of the Academic Division of International Studies, Chinese Academy of Social Sciences, dispatched a team of researchers to Darfur to conduct a social impact assessment on the presence of Chinese NOCs in Sudan. ${ }^{(57)}$

Some authors argue that NOCs operate under their own volition according to commercial interests and not at the direction of the Chinese government or in collaboration with the government. Other analysts argue that overseas energy investments are shaped by the Chinese government's strategic priorities. ${ }^{(58)}$ The Chinese emphasis on energy diplomacy reveals that various government ministries were in fact involved with, and had responsibilities for, furthering Chinese NOCs' oil and gas acquisitions overseas. The Ministry of Commerce supported an aggressive search for energy deals while the Ministry of Foreign Affairs preferred a more incremental approach that did not raise alarmist reactions that the Ministry's diplomats would have to manage. ${ }^{(59)}$

In March 2012, CCTV raised the question of whether China's diplomacy was overly dominated by energy diplomacy to the point of excluding other foreign policy interests and undermining other foreign policy objectives. ${ }^{(60)}$ NOCs were accused of only seeking profits, not contributing to China's energy security, losing money on their oil investments, and shipping only a portion of this oil back to China, a negligible amount compared to China's oil imports. ${ }^{(61)}$ And they were undermining the Chinese government's efforts at creating greater soft power for China.

48. Julie Jiang and Chen Ding, Update on Overseas Investments by China's National Oil Companies: Achievements and Challenges since 2011, OECD/IEA, 2014, p. 8.

49. "Zhongguo 'nengyuan zeren lun' keyi xiu yi" (The "theory of China's energy responsibility" can be laid to rest), art. cit.

50. Feng Yujun, Ding Xiaoxing, and Li Dong, "Russia's New Energy Diplomacy and Its Impact," Contemporary International Relations, Vol. 12, No. 10, 2002, pp. 1-17.

51. Gong Xuzheng, "Viewing China's Oil Diplomacy from the 'Angarsk-Daqing Line' Tussle," Guoji luntan, No. 6, November 2003, pp. 46-52, in Foreign Broadcast Information Service, 17 December 2003, CPP20031217.

52. Zhang Jianxin, Oil Security Reshapes China's Foreign Policy, Center on China's Transnational Relations Working Paper No. 9, The Hong Kong University of Science \& Technology, 2005, www.cctr.ust.hk/materials/working_papers/WorkingPaper9.pdf.

53. James Tang, "With the Grain or Against the Grain? Energy Security and Chinese Foreign Policy in the Hu Jintao Era," Brookings Institution working paper, October 2006, www.brookings.edu/ $\mathrm{fp} /$ cnaps/papers/tang2006.pdf.

54. Wang Haiyun and Xu Qinhua, Nengyuan waijiao gailun (Introduction to energy diplomacy), Beijing, Shehui kexue wenxian chubanshe, 2012, p. 4.

55. Philip Andrews-Speed and Roland Dannreuther, China, Oil, and Global Politics, London, Routledge, 2011, p. 77.

56. Erica Downs, "China's Global Energy Deals: Different Actors, Different Interests," Oil \& Gas for Asia, Washington, DC, 11 May 2012.

57. Richard McGregor, "Chinese Diplomacy 'Hijacked' by Companies," Financial Times, 17 March 2008.

58. Erica Downs, Inside China Inc.: China Development Bank's Cross Border Energy Deals, China Center Monograph No. 3, Brookings Institution, March 2011, p. 4.

59. Simon Shen, "Qualitative Energy Diplomacy in Central Asia: A Comparative Analysis of the Policies of the United States, Russia and China," Brookings Institution, April 2011, www.brookings.edu/research/papers/2011/05/04-us-russia-china-shen.

60. "Is China's Diplomacy Being Dominated by Energy Diplomacy?", CCTV, 12 March 2012, http://english.cntv.cn/program/newshour/20120312/115986.shtml.

61. "Haiwai zhaoyou: gai mei zhuan you ye mei zhuan qian" (Overseas to find oil: Neither earned oil nor made money), caipiao.163.com, 4 January 2012, http://news.163.com/12/ 0104/02/7MTOUTM200014JHT.html; Chen Shaofeng, "Has China's Foreign Energy Quest Enhanced Its Energy Security?", China Quarterly, No. 207, September 2011, pp. 600-625. 
The white paper on China Energy Policy 2012 reflected China's progress in international energy cooperation, although it repeated much of the content of the 2007 China Energy white paper. What was new in the China Energy Policy 2012 white paper was the mention of an "international energy management mechanism" as a means to maintain a stable global energy market, an indication of China's interest in global energy governance. ${ }^{(62)}$ In listing the organisations with Chinese participation, compared to the 2007 white paper, ASEAN+3 was omitted while the Group of 20 and the Shanghai Cooperation Organisation were added.

Zha Daojiong has noted that the world oil economy has many questions about Chinese NOCs' overseas oil investments, which the Chinese government has tried to mitigate with White Papers on Chinese Energy Policy. ${ }^{(63)}$ These white papers are produced for international consumption but are insufficient as perceptions of the Black Energy Swan persist, fuelled by China's expanding oil demand.

Energy reformers believe that China's domestic energy economy can evolve into a low-carbon economy through participation in global and regional energy governance. The International Energy Strategic Research Centre of Renmin University was established during China's 2003 energy crisis. The Centre has worked on China's energy diplomacy and other issues related to global energy governance. The Centre has published a series of reports since 2009. The most recent is International Energy Cooperation Report of China in 2011/2012. The organisations the report focuses on are both Western and non-Western: the IEA, OPEC, the Energy Charter, the International Energy Forum (IEF), the World Energy Council (WEC), the G20, the SCO, and the Gas Exporting Countries Forum (GECF). ${ }^{(64)}$

\section{BRICS energy governance}

Given both Chinese and Russian declarations on constructing a new world order, the newly formed BRICS provided the best opportunity to create a new kind of global energy governance. BRICS energy governance has several dimensions: BRICS energy demand and energy efficiency, BRICS NOCS, BRICS rules for a producer-consumer dialogue, and BRICS policies on the world energy market, either market-sustaining or market-blocking. This section is concerned with whether BRICS have the potential to construct an alternative world order in global energy governance.

The concept of BRIC was constructed by a Goldman Sachs executive in 2001 looking for a label for emerging economies, although he did not realise the impact these countries would have on global energy supply and demand. ${ }^{(65)}$ The IEA ranks Brazil fourth in energy consumption among its NonIEA Member Countries after China, India, and Russia. (66) Brazil became energy sufficient in 2006 and a net exporter of oil in 2011. South Africa is also a Non-IEA Member Country. ${ }^{(67)}$ India's energy security is the least stable of all the BRICS. ${ }^{(68)}$

All BRICS nations have national oil companies (NOCS), whether they are net-importers or net-exporters. The NOCs work very closely with their governments, making energy an important priority of the country's foreign policy. ${ }^{(69)}$ BRICS banks work closely with their NOCs, at the direction of the government, providing funding for oil investments. In China, the State Development Bank, Import and Export Bank, and other banks fund Chinese NOCs.

What BRICS have in common is that they are emerging economies rapidly consuming the world's hydrocarbons in unsustainable ways that contribute to global climate change. BRICS have energy intensive development, lacking the resources or the will to invest in energy efficiency. BRICS represent $40 \%$ of the world's population, with large portions of their populations relying on coal and other large portions of their populations still waiting for access to modern energy. The OECD worries that the largest of the BRICS, China and India, will "account for 95\% of energy demand growth to 2035." (70)

In 2008, the OECD predicted that the BRIC group by 2030 would consume more primary energy than the 30 OECD countries combined. The OECD's concern was the environmental impact from this rapidly expanding globalisation of energy demand. ${ }^{(71)}$ BRICS fiercely defend their right to development irrespective of the environmental consequences.

Among the BRICS countries, China in particular took offense at the IEA's concern with its exploding oil demand. As a group, BRICS generate world concern due to their contributions to greenhouse gases and climate change, although the BRICS do not form a cohesive bloc within international climate change meetings. ${ }^{(72)}$

Russia's inclusion was a little odd because it is not an emerging economy, but Moscow embraced the concept as it was looking for a vehicle to construct an alternative world energy order. Russia's focus was on creating a security-focused institution when it initiated the first BRIC Summit in 2009. South Africa joined in 2010, making it the "BRICS." Russian leadership of this bloc could happen only if the BRICS developed as an energy institution. The BRICS's stated purpose differs significantly from the Russian objective. The BRICS state that they want "peace, security, development and cooperation"; to find ways of "building a harmonious world of lasting peace and common prosperity" through "democratic and transparent decision-making." (73)

A review of BRICS history indicates that global energy governance concepts have emerged in BRICS summits, which have met annually since 2009. The Joint Statement of the BRIC Countries' Leaders at Yekaterinburg on 16 June 2009 emphasised the role of the $\mathrm{G} 20$ in responding to the global financial crisis of 2008, which should reconfigure the economic and financial global system in the aftermath of the crisis. An entire paragraph in the Yekaterinburg statement was devoted to energy:

We stand for strengthening coordination and cooperation among states in the energy field, including amongst energy producers and

62. Information Office of the State Council, China's Energy Policy 2012, 24 October 2012, www.gov.cn/english/official/2012-10/24/content_2250497.htm.

63. Zha Daojiong, "The Search for Energy Security," in Ashley J. Tellis and Sean Mirski (eds), Crux of Asia: China, India and the Emerging Global Order, op. cit., p. 215.

64. Chen Yue and Xu Qinhua (eds), China International Energy Cooperation Report 2011/2012: Towards Low Carbon Era's Global and Regional Energy Governance, Beijing, Current Affairs Publishing House, 2012.

65. John Daly, "BRIC's Achilles Heel - Energy," Oilprice.com, 27 June 2012, http://oilprice.com/ Energy/Energy-General/BRICs-Achilles-Heel-Energy.html.

66. IEA, "Brazil (Partner Country)," www.iea.org/countries/non-membercountries/brazil.

67. IEA, "South Africa (Partner Country)," www.iea.org/countries/non-membercountries/southafrica.

68. Charles K. Ebinger and Govinda Avasarala, "The Energy-Poor BRIC," Brookings, 19 October 2012, www.brookings.edu/research/opinions/2012/10/19-energy-bric-ebinger-avasarala.

69. Draga Claudia Marin, "The Strategies of Brics' National Oil Companies for Energy Security: Joint Ventures Bargaining and Vertical Integration," Paris-Dauphine University, 2012, www.usaee.org/usaee2012/submissions/OnlineProceedings/MarinPaper.pdf.

70. OECD, IEA, OECD Green Growth Studies: Energy, 2011, www.oecd.org/greengrowth/greening-energy/49157219.pdf.

71. D Ravi Kanth, "BRIC Set to Beat Rich Nations in Energy Use by 2030: OECD," Rediff India Abroad, 8 March 2008, www.rediff.com/money/2008/mar/08bric.htm.

72. Christian Brütsch and Mihaela Papa, Deconstructing the BRICS: Bargaining Coalition, Imagined Community or Geopolitical Fad?, Working Paper No. 5, CRP Working Paper Series, October 2012, www.crp.polis.cam.ac.uk/documents/working-papers/crp-working-paper-5-brutsch-and-papa.pdf.

73. BRICS Forum, "Joint Statement of the BRIC Countries' Leaders," 16 June 2009, Yekaterinburg, www.bricsforum.com/yekaterinburg. 
consumers and transit states, in an effort to decrease uncertainty and ensure stability and sustainability. We support diversification of energy resources and supply, including renewable energy, security of energy transit routes and creation of new energy investments and infrastructure. ${ }^{(74)}$

The 2009 BRIC summit supported the concept of producer-consumertransit state dialogue, supported diversification of types of energy and sources of supply, and supported cooperation in energy infrastructure. The BRICs supported sustainability and stability. On these principles, BRIC policy on energy did not diverge from international energy institutions and did not seem like an alternative world energy order.

The 2010 Brasilia Summit Statement stressed access to modern energy as necessary to economic growth, access to affordable, clean, and sustainable energy, and supported BRIC cooperation in energy efficiency, R\&D, training and technology transfer. ${ }^{75)}$

The 2011 Sanya Summit created an Action Plan and began to thicken networks and linkages among the members. The Sanya Declaration opposed excessive volatility in world commodity prices, especially energy, and emphasised the need to strengthen producer-consumer dialogue for the purpose of achieving a better balance of supply and demand. The Declaration also supported cooperation on renewable energy and nuclear energy. ${ }^{(76)}$

The 2012 Delhi Summit produced a Delhi Declaration and a Delhi Action Plan. The Declaration stressed strengthening producer-consumer dialogues, especially in food and energy, to counter excessive volatility in commodities markets. It recognised Iran's right to develop nuclear energy that was consistent with IEAE oversight. The Delhi Action Plan included exploring the possibility of a BRICS framework for multilateral energy cooperation, creating the possibility of an alternative world energy order.

The 2013 Durban Summit in South Africa was expected to create a BRICS development bank, a business council, and a network of think tanks. Funding for a $\$ 100$ billion stabilisation fund depended on China, which would contribute $\$ 41$ billion, while South Africa would contribute $\$ 5$ billion, with $\$ 18$ billion each from the other BRICS countries. (77) Energy and food security had been stated priorities prior to the summit. The National Union of Metalworkers of South Africa made formation of a BRICS energy mechanism a test of whether BRICS as an organisation was viable, stating, "The question of energy, its production, supply and consumption will be a litmus test of whether the constellation known as BRICS (Brazil, Russia, India, China and South Africa) is a coherent political entity." (78) The Union claimed that for BRICS to continue their rapid economic growth, they would need sufficient and reliable supplies of energy.

China treated the 2013 Summit as an opportunity to develop strategic partnerships between China and Africa, and further develop oil relations. President Xi Jinping held a side meeting with African leaders during the summit to explore further areas of cooperation. ${ }^{(79)}$

Russia continued to encourage institutionalisation of the BRICS framework. It was Russia that followed-up on the Delhi Action Plan, issuing a concept paper from the Kremlin on Russia in the BRICS on the eve of the 2013 Durban Summit. One entire section was devoted to Russian objectives in BRICS energy cooperation: energy security for Russia and other BRICS, longterm supply contracts, a legal framework for energy cooperation (rules and institutions), joint research and technology exchanges for energy efficiency and renewable energies. According to this Kremlin concept paper, Russia would take the lead in BRICS energy governance:
In order to fulfill these objectives the Russian Federation will actively participate in the creation of mechanisms for the multilateral cooperation of BRICS states in the sphere of energy, such as the Energy Dialogue. ${ }^{(80)}$

The concept paper reiterates much of what was in the 2009 Yekaterinburg statement. This potential BRICS mechanism would create an alternative global energy governance structure focused on a producer-consumer dialogue.

The BRICS 2013 Summit failed to address the Russian proposal and failed to create an energy multilateral mechanism. The $5^{\text {th }}$ BRICS Summit issued the BRICS and Africa: Partnership for Development, Integration and Industrialization: eThekwini Declaration and Action Plan, in which there was no mention of energy except at the end as a new area of cooperation to be explored at future meetings. ${ }^{(81)}$

Numerous differences exist according to Chinese scholars: "Russia emphasizes reforming the current international finance system; South Africa calls for protection of African interests; India and Brazil try to make the BRICS mechanism as the stepping stone to becoming permanent members of UN Security Council." (82) Russia and China oppose the UN Security Council expanding its membership. In addition, Beijing promoted the China Model, which did not represent the BRICS model.

China argues that the purpose of BRICS is: to reform global governance, give a larger voice to emerging economies, and to "democratise international relations," which means providing a counterweight to US power. Beijing expects the BRICS to function as a bloc supporting Chinese initiatives in the world economy and polity. Russia hopes that BRICS will form into a bloc and provide a sphere of influence for Moscow that would give it an equal footing with the US.

By the 2013 BRICS Summit, Russia was still hoping that the BRICS would take on a geopolitical role, would develop a unified position on a range of issues, and would recognise Russian leadership. The Summit's minimal mention of energy indicates that other BRICS countries were not ready for Russian leadership or an energy mechanism.

Russian newspapers expressed disappointment with the lack of concrete outcomes, calling the BRICS a dialogue rather than a mechanism that would form only part of the global governance system. ${ }^{(83)}$ In his address to the

74. Ibid.

75. University of Toronto, BRICS Information Centre, "2nd BRIC Summit of Heads of State and Government: Joint Statement, Brasília, April 15, 2010," www.brics.utoronto.ca/docs/100415leaders.html.

76. University of Toronto, BRICS Information Centre, "Sanya Declaration, Sanya, Hainan, China, April 14, 2011," www.brics.utoronto.ca/docs/110414-leaders.html.

77. New Development Bank BRICS website, http://ndbbrics.org/cn.html.

78. "S. African Union Urges Energy Coordination at BRICS Summit," English.news.cn, 23 March 2013, http://news.xinhuanet.com/english/world/2013-03/23/c_132255665.htm.

79. "China 'Firmly Supports' BRICS," China Daily, 25 February 2013, www.chinadaily.com.cn/cndy/ 2013-02/25/content_16252364.htm.

80. Kremlin, "Concept of Participation of the Russian Federation in BRICS," 21 March 2013, http://eng.news.kremlin.ru/media/events/eng/files/41d452b13d9c2624d228.pdf.

81. University of Toronto, BRICS Information Centre, "BRICS and Africa: Partnership for Development, Integration and Industrialisation, eThekwini Declaration Durban, South Africa, March 27, 2013," www.brics.utoronto.ca/docs/130327-statement.html.

82. Zhang Wenru and Li Zhiwei, "The Rise of BRICS: Strategic Basis, Cooperation Agenda and International Influence," International Strategic Studies, No. 3, 2011, serial No. 101, pp. 47-56, China Institute for International Strategic Studies, Beijing.

83. "BRICS Holds Summit in Africa," ITAR-TASS, Russian Press Review, 28 March 2013, http://tass.ru/en/russianpress/691503. 
Summit, Putin had called for co-financing in green economy projects, ${ }^{(84)}$ but since the summit could not move forward on the BRICS development bank, it was premature to consider financing green energy projects. There was nothing in the Summit Declaration about green economy projects, although it did acknowledge that climate change was a challenge to sustainable development.

At the July 2014 BRICS Summit in Brazil, the BRICS signed an agreement to create the $\$ 100$ billion BRICS Development Bank with a reserve currency pool worth over another $\$ 100$ billion. It would later be called the New Development Bank (NDB) with headquarters in Shanghai. NDB has shared leadership, with each member country having a vote, no country having veto power, and leadership positions distributed among the BRICS. NDB was to begin lending in 2016.

In July 2015, Moscow hosted the $7^{\text {th }}$ BRICS summit, combining it with the $15^{\text {th }}$ Shanghai Cooperation Organisation summit and an informal meeting of the Eurasian Economic Union (EEU). It was a diplomatic manoeuver that managed to subsume the BRICS and the SCO into the EEU, realising Putin's vision of Eurasian integration under an organisation where Russia has a clear leadership role. Moscow demonstrated that it was not isolated by Western sanctions.

Moscow introduced some energy initiatives. Russia and South Africa signed an energy MoU for a Russian-built nuclear power plant in South Africa. Moscow initiated a meeting of the BRICS Heads of Industrial and Energy Safety Authorities. The $7^{\text {th }}$ BRICS Summit Ufa Declaration had a section on energy, Item No. 69 at the bottom, which called for BRICS energy cooperation, noted the first BRICS meeting on energy efficiency in May 2015, and acknowledged the Russian proposal to hold a meeting of the BRICS' Ministers of Energy at an unspecified time. Overall, it was not successful in creating a BRICS energy organisation.

The NDB was officially launched after many weeks of wrangling over its rules and policies. NDB will have an initial capitalisation of $\$ 100$ billion. The NDB was a necessary component in constructing a role for BRICS in global energy governance. Yet it did not clearly demonstrate China's leadership role in global energy governance because of the shared leadership model and because Russia intended to assert its leadership role in a BRICS energy mechanism. Beijing remained frustrated with the slow pace and contentiousness in forming the NDB, moving on to the Asian Infrastructure Investment Bank (AIIB), where Beijing had a clear leadership role.

The possibility that BRICS will shape a new global architecture in energy, or that they will impact the world political and economic order with a new theory of international energy institutions, seems remote. Given that all the BRICS are in the global ungoverned energy space, and that they are a very disparate group of states, makes theorising about alternative global energy governance an impossible task. At this juncture, it is only a possibility. BRICS is an acronym that still needs to prove its substance for global energy governance.

\section{Conclusion}

China continues to seek participation in the current global energy governance system, contributing to its reform even though this would lead to continual pressure for Chinese domestic energy policy reform. At the same time, China seeks to create an alternative global energy order using the framework of the BRICS and the SCO.

For Beijing, the BRICS organisation is a means for influencing the existing global energy governance order as part of a coalition. According to Zhu
Jiejin, Centre for BRICS Studies in Fudan University, "(...) China is neither with nor against western powers (...). China accepts the existing framework while trying to make changes to it. It will be better for China to seek these changes together with India, Russia, Brazil and South Africa than going it alone." (85)

The liberal institutionalist approach needs modification based on its application to the BRICS. China's efforts to create an alternative global energy order by creating international institutions, the BRICS and later the Silk Road Economic Belt, has not followed the path of the IEA. The IEA has tried to impose best practices and transparency on the world oil economy's "dark underbelly" of corruption in oil producing states. China's institution building has not made any reformist demands on corrupt BRICS oil exporters/importers, nor has it done so with corrupt Central Asian countries along the New Silk Road Economic Belt. The liberal institutionalist approach should be modified to be less value-laden, which would make the approach more applicable to illiberal states. We should not assume that international institutions are constructed to promote best practices, transparency, and corruption avoidance.

International relations theory has yet to adjust to a non-Western world order. Chinese international relations theory, in all its variations, has a Chinese audience but has not been adopted by the BRICS. The BRICS may never devise an international relations theory for themselves as they are an improbable collection of states who trade more with the West than with each other. BRICS membership includes two net exporting countries and three net importing countries. Whatever theory of international energy institutions BRICS would devise must reflect the interests of both exporting and importing nations.

Wang Jisi's work on Chinese perceptions of the evolving global order argues that China has shifted from promoting a new international order to calling for a more "just and equitable" global order. China is advocating reform of the current global order rather than its displacement, and expects to achieve greater representation in international institutions such as the World Bank, IMF, and WTO. Global governance participation will not change the essential authoritarian nature of the Chinese state. ${ }^{\left({ }^{86}\right)}$

Chinese membership in the BRICS and SCO organisations facilitates Chinese NOC oil and gas investments in member countries. This may be the primary function of these organisations rather than formation of an alternative global energy governance order.

BRICS as an organisation appears not yet ready to fill the global energy governance deficit. Chinese analysts such as Xu Xiaojie promote a BRICS energy cooperation mechanism that could lead to cooperation at the global level, placing the BRICS "(...) at the forefront of multilateral innovation and institution building in a critical area of global governance." (87) The mechanism's purpose would be to "(...) challenge current global governance systems dominated by Western economies, and lead to the formation of a new global governance system." (88) Xu hopes BRICS could "(...) coordinate their

84. Kremlin, "Speech at BRICS Summit Talks in Expanded Format," 27 March 2013, http://eng. kremlin.ru/transcripts/5179.

85. Malcolm Scott, "Here's the \$17 Trillion Reason Why the BRICS Summit This Week Is a Big Deal," Bloomberg News, 6 July 2015.

86. Wang Jisi, "Changing Global Order: China's Perspective," in Ashley J. Tellis and Sean Mirski (eds), Crux of Asia: China, India and the Emerging Global Order, op. cit.

87. Xu Xiaojie, "Energy BRICS: Towards a New Cooperation Framework," 9 April 2012, http://english.cssn.cn/opinion/201311/t20131130_889837.shtml. Xu Xiaojie is senior research fellow and director of World Energy Division, Institute of World Economics and Politics, Chinese Academy of Social Sciences. 
positions so that they can speak with a common voice in forums such as the International Energy Forum (IEF)." (89)

However, the BRICS cannot be the vehicle for Chinese leadership of global governance. The BRICS practice shared leadership, and Russia continues to hold expectations that the BRICS will be an arena for Russian leadership. The Shanghai Cooperation Organisation had a similar problem of Beijing contending with Moscow for leadership of the regime.

The vehicle for uncontested Chinese leadership was announced in 2013 as the "Silk Road Economic Belt," an effort to create a new economic order with Central Asia and the Middle East. The primary focus of SREB is for China to build transport infrastructure in Central Asia and export surplus Chinese capacity in cement, aluminium, and steel in building the infrastructure. As proposed by Xi Jinping in September 2013, SREB will "consist of a network of railways, highways and other forms of infrastructure, as well as oil and gas pipelines, power grids, internet networks and aviation routes in the Eurasian area." (90)

Chinese NOCs have been investing in Central Asian oil and gas since the 1990s. SREB, however, is meant to create a land bridge that encompasses Central Asian and Middle Eastern oil exporting countries within a geopolitical framework that will bind these energy producing regions closer to China. China perceives pipelines as more secure than energy brought via maritime routes. It is the "Eurasian Land Bridge" concept discussed by Chinese analysts in the 1990s.

Existing energy infrastructure includes the Trans-Asia Gas Pipeline, from Turkmenistan to China, passing through Uzbekistan and Kazakhstan, and the Kazakhstan-China oil pipeline. The fourth pipeline, to be completed in 2020, has been designated a SREB project although the previous three pipelines predate the Silk Road project. ${ }^{(91)}$

Further explanation of the Silk Road energy order was offered at a conference on "Strengthening Energy Cooperation in the One Belt One Road Regions," 15-16 June 2015, organised by the Global Forum on Energy Security (GFES). The Forum is China's international platform for consulting on transformations in global energy governance and China's role in it. The GFES 2015 was co-organised by Chinese institutions, the United States Energy Security Council, and the Chinese Energy Fund Committee, an NGO that appears to be a mechanism for US-China energy dialogue.

The CCP's $18^{\text {th }}$ Party Congress initiated Xi Jinping's foreign policy of greater Chinese assertiveness and schemes to restructure the regional and global order. ${ }^{\left({ }^{2} 2\right)}$ Chinese NOCs were instructed to define their contribution to regional projects such as the New Silk Road project. ${ }^{(93)}$ The Chinese Foreign Ministry was tasked with energy diplomacy along the Silk Road. ${ }^{(94)}$

In World Energy China Outlook 2014-2015, Xu Xiaojie urged Chinese energy companies to shift their strategy of "Going out" toward the "Silk Road" strategic concept. ${ }^{(95)}$ This was only three years after Xu called for emphasising BRICS.

It would seem that China is participating in global energy governance while constructing an alternative Silk Road energy order. It is unlikely that the Silk Road energy order with Central Asia and the Middle East will become an autonomous energy system, but rather will be incorporated into the larger global energy governance system.

Chinese economic growth has slowed, resulting in reduced demand for oil imports. Nevertheless, in April 2015 China became the world's largest oil importer, and its domestic energy ungoverned spaces became a problem for world oil markets.

China's domestic capacity for participating in global energy governance is nevertheless still very weak. China's hope is that global participation will strengthen and modernise China's energy management capacity both domestically and internationally.

I Gaye Christoffersen is resident professor of international politics, Johns Hopkins University, Nanjing Center.

Hopkins-Nanjing Center, Nanjing University, 162 Shanghai Road, Nanjing, Jiangsu Province, China 210093 (gchris14@jhu.edu).
88. Ibid.

89. Ibid.

90. Xinhua, "'One Belt, One Road' Initiatives Offer Opportunities for Eurasia: Chinese Scholar," China.org.cn, 24 March 2015, www.china.org.cn/world/Off_the_Wire/2015-03/24/content_351 39901.htm.

91. Erica Downs, "Mission Mostly Accomplished: China's Energy Trade and Investment Along the Silk Road Economic Belt," China Brief, Vol. XV, No. 6, 19 March 2015, pp. 2-5.

92. Qinhua Xu and William Chung, China Energy Policy in National and International Perspectives: A Study Fore and Aft 18th National Congress, Hong Kong, City University of Hong Kong Press, 2014.

93. CNPC Economics \& Technology Research Institute, Report on Oil \& Gas Industry Development in 2014, January 2015, p. 34.

94. Shi Ze and Yang Chenxi, China's Diplomatic Efforts to Promote Energy and Resources Cooperation Along the "One Belt and One Road," CIIS Report No. 5, May 2015.

95. Xu Xiaojie, "Shijie nengyuan Zhongguo zhanwang (2014-2015)" (World energy China outlook, 2014-2015), Beijing, Zhongguo shehui kexue chubanshe, February 2015 